\title{
Measuring Integrated Rural Tourism
}

Gordon Clark* and Mary Chabrel

Department of Geography, Lancaster University, Lancaster LA1 4YB, UK. Tel.:

01524 593740. Fax: 01524 847099. Email g.clark@lancaster.ac.uk

* Contact person

Gordon Clark is Senior Lecturer in geography at Lancaster University. He led the Lancaster team in the SPRITE project.

Mary Chabrel was the research associate on the SPRITE project in Lancaster. 


\section{Measuring Integrated Rural Tourism}

ABSTRACT If the concept of integrated rural tourism, as developed in the SPRITE project, is to be used as an operational tool to assess the all-round value of tourism in rural areas, there needs to be a means of measuring the value of tourism, and changes in it. Statistical, 'objective' methods of achieving this are critiqued. This paper describes the development of an alternative methodology for assessing the changes in the value of tourism witnessed by different groups of stakeholders in the study areas across Europe between 1992 and 2002. The methodology allows for a holistic view of the extent to which rural tourism is integrated into the local economies and cultures. Differences in perceptions regarding change in the value of tourism between actor groups and countries are noted. Illustrative examples are given of specific events and forms of rural tourism that are perceived as being of high value. It is concluded that while tourism is now better integrated than it was ten years ago, further improvements can be made in identifiable areas and dimensions and for particular actor groups.

KEY WORDS: Integrated tourism, rural areas, tourism value methodology, stakeholders.

\section{Introduction}

The SPRITE project was concerned to assess the dimensions on which tourism can be and has been integrated within lagging rural regions across Europe and to make 
recommendations on how such integration might be further improved. 'Integration' implies constructing a holistic profile of tourism's range of consequences for an area - environmental, socio-cultural and economic. This fits within the culture economy approach taken by the SPRITE project as a whole (see the introductory paper by Saxena et al., 2007; Stabler, 1997; Swarbrooke, 1999).

The assumption is that well integrated tourism creates more value than tourism that is poorly integrated. However, the multi-dimensional span of the assessment of tourism's effects makes it difficult to measure the degree of integration or the 'value' of tourism. Without such measurement it is difficult to envisage how one might comment in any detail on whether tourism's degree of integration has improved, let alone to what extent, in what respects, and why it has changed, or for whom it has improved and in which types of rural area.

This paper reports on the development of a holistic method of measuring the degree of integration of tourism on several dimensions as perceived by various actor groups, and the recent changes in this 'integration value'.

\section{Measuring tourism's 'integration value’}

The literature on sustainable tourism has coalesced around a view that, to be truly sustainable, tourism needs to meet high standards not only within the environmental sphere but also in terms of its social and economic effects (Ryan, 2002; Hemphill, Berry and McGreal, 2004; Jenkins and Oliver, 2001; Saxena, et al., 2007). Tourism should protect the environment, support host communities, maintain the profitability 
of businesses and satisfy the visitors. The ideal tourism goes beyond 'win, win' to multiple wins. Numerous policy documents about the management of tourism in rural areas incorporate this model of all-round benefit as the target (World Tourism Organization, 2001; Commission of the European Communities, 2003). These documents attest to the desire for the concept of integrated tourism (or all-round sustainable tourism as it is also called) to be more than a concept. It should become a guide to practical action and policy even though sustainable tourism as a concept contains several potential contradictions (Cater, 1994).

This sets a very high standard of perfection that is analogous to the economist's concept of Pareto optimality. A Pareto optimal form of development is one in which some people benefit and no one is made any worse off by it. The Pareto principle underlies the definition of sustainable tourism as necessarily having economic, environmental and social/cultural dimensions. This is equivalent to the Rawlsian notion of fairness and of the wider multi-dimensional definition of integrated tourism used in the SPRITE project (see Saxena et al., 2007 for further details; Butler, 1999). Trading off gains from tourism on one dimension against losses on another will redistribute tourism's effects but it will not necessarily lead to any net advantage from having tourism develop in an area. Integrated tourism finds trade-offs problematic, unlike the literature on balanced development where compromises can be acceptable, and gains of sufficient importance can outweigh losses, provided that the net benefit is large enough. The best form of tourism would be one which achieves gains on all dimensions and for all groups. It would not, for example, protect the environment by disadvantaging businesses, or benefit businesses at the expense of the host communities. In theory a form of tourism which corresponds to an ideal of total 
sustainability may be achieved some day, but in reality tourism policy aims to move tourism along a continuum from a lesser to a greater sustainability. This requires a means of measuring the degree of sustainability of actual tourism situations so that progress can be detected and measured. If the definition of tourism sustainability integrated into everyday life is multi-dimensional, then the methods of measuring the degree of integration also need to be multi-dimensional (McCool \& Moisey, 2001; Aronsson, 2000).

The SPRITE project worked with the seven dimensions of integration which were central to the research (Table 1) (Saxena, et al., 2007). Together these dimensions encompass the measurement of the environmental, economic, social, cultural and political effects of tourism in ways which people on the ground can assess when interviewed.

\section{Table 1 Seven dimensions of tourism integration}

Networking - The ability of people, firms and agencies in the locality and beyond to work together to develop and manage tourism.

Scale - The extent of tourism in an area in terms of its distribution over time and geographically, bearing in mind any thresholds related to the area's carrying capacity.

Endogeneity - The degree to which the area's tourism is recognised as being based on the real resources of the area. 
Sustainability - meaning here the extent to which tourism does not damage, and possibly enhances, the environmental and ecological resources of the area.

Embeddedness - the role tourism plays in the politics, culture and life of the whole area and population as a local priority.

Complementarity - the degree to which tourism provides resources or facilities which benefit those who live locally in the area even if not directly involved in the tourism industry.

Empowerment - the extent of political control over the tourism industry through ownership, law or planning; particularly control exercised at a local level.

\section{Statistical measures of integration}

The option of using statistical measures of tourism's degree of integration is appealing because of its potential objectivity. The variables can be quantified, monitored over time, and trends and levels can be compared spatially and among stakeholders. The difficulties with this approach are more practical and can be summarised under the headings of variables, methods and summation.

First, one has to select a set of variables which captures the relevant aspects of tourism's effects comprehensively rather than partially, on each of the seven dimensions for integration (Table 1). Conceivably one might need several measures of tourism's economic and environmental effects to cover all their aspects of change. The IRENA project to measure the sustainability of agriculture, for example, used 39 
very diverse indicators of agriculture's effects (European Environment Agency, 2005). Data for these measures need to be available over a sufficient period for any trends to be discernible; to be available for small and large areas, and for each of the participating countries (this research was conducted in six countries). The more countries are involved, the more difficult it is to achieve this international comparability in the database. Without a commonality of data, valid spatial comparisons are not possible.

Second, the data must have been collected using a methodology that is at least roughly similar in each area or country and historically. This includes matters such as the dates and places of surveys (tourism has marked seasonalities and market segmentation), coverage and data reliability. Without this methodological and historical commonality of data, ascribing changes to real events on the ground rather than to methodological inconsistency will be impossible. Additionally each direction of change on each variable needs to be clearly classifiable as pro- or antisustainability. For tourism particularly, this process of classification may itself be contentious. For example, are more tourists desirable? Or is the answer to this question highly contextual and liable to split the community?

The third problem is summation. To go beyond single-issue measures of tourism's effects, one needs to be able to 'add' the individual, single-dimension measures (and there could be several on any one dimension) to give an overall 'score'. Without this, one is still just measuring individual elements of tourism rather than its integratedness. This process of summation requires a common metric of scale and change in tourism's effects. Otherwise one cannot 'add', for example, 20 new tourism 
jobs in a village and a 10 per cent reduction in dissolved oxygen (a measure of declining water quality) in the village's river downstream from its sewage works. Yet only by such a process of 'addition' can one get an overall judgment of tourism's effects, even with just these two variables which use very different measures of change.

In conclusion, while statistical methods of measuring the integratedness of tourism are attractive at first sight, in practice the requirements of data availability and comparability are difficult to achieve (Miller \& Twining-Ward, 2005). Additionally the data requirements become more onerous the more fully one seeks to capture each dimension, the more countries are involved and the longer the time span one wishes to use for historical comparisons.

Hence in this paper an alternative approach, used in the SPRITE project, is reported. Instead of using directly whatever statistics are available, the method is based on the perceived changes on each dimension identified by the various actor groups - the communities, gatekeepers, institutions, resource controllers, visitors and businesses (see Saxena, et al., 2007 for details of the actor groups). It is through the clustering in time and spaces of these actor groups that a tourist resort is created and tourism experiences elaborated (Stabell and Fjeldstad, 1998; Talluri, Baker and Sarkis, 1999). Each respondent was free to use whatever data, observations or experiences they had, when making their judgment. Residents and agencies had mostly been operating in the area for the ten-year period covered in this research (1992-2002). So, this method measures relative changes in tourism integration (2002 compared with 1992) and not any absolute agree of integration. Only more experienced staff were interviewed. 
Many of the visitors were repeat visitors; first-timers were excluded for this phase of the research. In each study area a representative sample of stakeholders was interviewed about their views on all aspects of tourism in their study area. So, the businesses were asked not only about their own businesses but about local networking and the overall scale of tourism, and about the five other dimensions in Table 1. Members of the host communities were asked about their degree of control over tourism and about how much tourism complemented other aspects of life locally. The tourists were asked about the environmental effects of tourism as well as about their personal experiences as tourists.

Each national team of researchers was given a detailed briefing paper by the lead (Lancaster) team that described which questions from the surveys of each stakeholder group should be examined to determine each individual's views on each of the seven dimensions (see Table 1). The teams were then told how to combine the individuals' responses into a study-area view, based on the modal response for each dimension and stakeholder, with outlier responses being described separately. Since it is perceived change that is being measured, the measurement scale was kept simple. The direction of change was measured as either positive or negative over the whole period and for the study area as a whole (for example, greater or lesser endogeneity; more or less empowering). The degree of change was judged as either minor, moderate or major in scale, each being given a ranked numerical value of 1,2 or 3 , for operational reasons which will be discussed later. A score of 0 signified 'no change'. The tenyear time span is probably the maximum possible with this method if one wants a large number of reliable respondents (over 100 tourists in each area, for example), allowing for staff turnover, new agencies being formed, migration of residents and the 
frailties of memory. The results are in effect smoothed by being given for the period and study areas as a whole. One could have fine tuned the historical and spatial scales if one had wanted more details (for shorter periods or sub-areas, for example), but that was not pursued in this project.

The use of perceived change is not without its problems - memory distortions, 'averaging' over time, space and individual elements, and ambivalences over the desirability of particular changes. But by creating a common metric for disparate phenomena, the method does allow for the first time the integration of each dimension's results and comparisons between areas, dimensions and stakeholders (as will be shown below). It is arguable that it is the perceptions of tourism held by the visitors, hosts and agencies that is the real political driver of policy, and not straightforwardly the statistics of change. Sustainable tourism, like sustainable development generally, is a way of thinking that is socially constructed around what changes ought to be taking place, rather than a simple conclusion from a set of uncontentious data. While the perceptions will be influenced by the available statistics and their specialist and lay interpretations, the perceptions cannot be reduced to those data. The approach used in this research incorporates the local actors and their critical judgments on changes rather than imposing the researcher's views. This actor-based approach to measuring value change fits with experience-based approaches to the study of tourism (Stamboulis and Skayannis, 2003).

\section{Value-change across the dimensions}

The seven dimensions of tourism integration described in Table 1 were explored in surveys of the six actor groups in each of the 12 study areas (see Saxena et al., 2007 
for details of the areas). By gathering together the perceptions of change on the seven dimensions, as described above, one can gain an overall profile of where and how integration across the dimensions has occurred. If the tourism sector in each study area had been perceived by every actor group to have undergone a major and positive improvement on each dimension between 1992 and 2002 ( +3 scores throughout), then across all the study areas a total score of 1512 would have been achieved. In fact the actor groups in the different study areas varied in their perception of the effects of tourism, and a total score of only 782 (or 51.7 per cent of the theoretical maximum) was achieved. This paper will now show which dimensions offered the most improvement and which the least, and whether this was a consistent judgment among the actor groups and countries. Examples of high-value, well-integrated tourism will also be given to illustrate the changes. This will show where further improvements should be targeted to achieve a fully integrated tourism.

Table 2 shows the scores for each of the dimensions. If each actor group in every study area had seen a 'major improvement' in the value added to their area by tourism between 1992 and 2002, then that dimension would have achieved the maximum score of 216. Empowerment came closest to that unanimous perception of theoretical perfection, and complementarity was furthest from it, having obtained 23 per cent less support than empowerment (96 compared with 125). 
Table 2 Value-added scores by the dimensions

\begin{tabular}{|l|l|l|}
\hline Node of Tourism Value & $\begin{array}{l}\text { Value change } \\
\text { (maximum }=216)\end{array}$ & $\begin{array}{l}\text { Percentage of } \\
\text { maximum }\end{array}$ \\
\hline Empowerment & 125 & 57.9 \\
\hline Scale & 115 & 53.2 \\
\hline Sustainability & 115 & 53.2 \\
\hline Endogeneity & 114 & 52.8 \\
\hline Embeddedness & 110 & 50.9 \\
\hline Networking & 107 & 49.5 \\
\hline Complementarity & 96 & 44.4 \\
\hline
\end{tabular}

It can be shown that the level of support for each of the dimensions was obtained in differing amounts from among the various actor groups - Table 3 disaggregates by actor group the data in Table 2. Overall the actor groups had similar totals for the overall amounts of value added they had detected from tourism's development between 124 and 138 out of a theoretical maximum of 252 for each group. However, they differed considerably in their assessments of which of the seven dimensions of tourism they saw as particularly improving. 
Table 3 Value-added by actor group and dimension (node scores in brackets)

\begin{tabular}{|c|c|c|c|c|}
\hline Actor Group & $\begin{array}{l}\text { Total value } \\
\text { added and } \\
\% \text { of total } \\
\text { (252) }\end{array}$ & $\begin{array}{l}\text { Most value-added } \\
\text { nodes }(\text { maximum }= \\
\text { 36) }\end{array}$ & $\begin{array}{l}\text { Least value-added } \\
(\text { maximum }=36)\end{array}$ & \\
\hline Tourists & $50.8 \%$ & $\begin{array}{l}\text { Scale } \\
\text { Empowerment } \\
\text { Complementarity (20) }\end{array}$ & $\begin{array}{l}\text { Networking } \\
\text { Endogeneity } \\
\text { Sustainability }\end{array}$ & $\begin{array}{l}(13) \\
(16) \\
(17)\end{array}$ \\
\hline Gatekeepers & $52.4 \%$ & $\begin{array}{ll}\text { Endogeneity } & (24) \\
\text { Empowerment } & (21) \\
\text { Embeddedness } & (20) \\
\text { Networking } & (20)\end{array}$ & $\begin{array}{l}\text { Scale } \\
\text { Complementarity } \\
\text { Sustainability }\end{array}$ & $\begin{array}{l}(13) \\
(15) \\
(19)\end{array}$ \\
\hline Businesses & $49.2 \%$ & $\begin{array}{ll}\text { Scale } & (22) \\
\text { Sustainability } & (21) \\
\text { Empowerment } & (20)\end{array}$ & $\begin{array}{l}\text { Embeddedness } \\
\text { Complementarity } \\
\text { Endogeneity }\end{array}$ & $\begin{array}{l}(11) \\
(15) \\
(16)\end{array}$ \\
\hline $\begin{array}{l}\text { Resource } \\
\text { Controllers }\end{array}$ & $50.4 \%$ & $\begin{array}{ll}\text { Endogeneity } & (25) \\
\text { Embeddedness } & (24) \\
\text { Empowerment } & (20)\end{array}$ & $\begin{array}{l}\text { Scale } \\
\text { Complementarity } \\
\text { Sustainability } \\
\text { Networking }\end{array}$ & $\begin{array}{l}(11) \\
(11) \\
(18) \\
(18)\end{array}$ \\
\hline $\begin{array}{l}\text { Host } \\
\text { Communities }\end{array}$ & $52.8 \%$ & $\begin{array}{l}\text { Complementarity (24) } \\
\text { Empowerment } \\
\text { Embeddedness }\end{array}$ & $\begin{array}{l}\text { Sustainability } \\
\text { Endogeneity } \\
\text { Networking }\end{array}$ & $\begin{array}{l}(16) \\
(16) \\
(16)\end{array}$ \\
\hline Institutions & 138 & $\begin{array}{ll}\text { Scale } & (26) \\
\text { Sustainability }\end{array}$ & $\begin{array}{l}\text { Complementarity } \\
\text { Embeddedness }\end{array}$ & $\begin{array}{l}(11) \\
(16)\end{array}$ \\
\hline
\end{tabular}




\begin{tabular}{|l|l|l|l|}
\hline & $54.8 \%$ & Empowerment (23) & Endogeneity (17) \\
\hline Total (max. $=$ & 782 & & \\
$1512)$ & $51.7 \%$ & & \\
\hline
\end{tabular}

Taking each dimension in turn, examples are given below of projects and practices that had added value and better integrated tourism.

\section{Empowerment}

There was unanimity among the actor groups as to the improvement on this dimension. Every actor group saw empowerment as one of the top three areas of improvement (Table 3). This includes the host communities, potentially the group who might be left behind if externally controlled, unsympathetic tourism had radically changed their area.

Examples of the empowering effects of rural tourism include the following:

- the growth of local tourism groups in Slavonice (Česká Kanada, Czech Republic) especially the Renaissance Society to control the development of this World Heritage Site for increased tourism;

- the use of the Route des Métiers in Auvergne (France) as a social network for local people, semi-independent of the public authorities which run the Regional Park; 
- GaelSaoire in the West Region (Ireland) which, while government funded, has developed festivals which allow local people to revive cultural traditions for new audiences and sell local products to the increased numbers of festival visitors;

- Terra Ferma, a hill-walking holiday group in Valencia (Spain) which has improved the area's sense of local self-worth by bringing appreciative foreign tourists into a formerly little-visited area;

- the Marches Tours and Talks on the England / Wales Border which use local people as guides and so ensure that the economic returns do not leak out of the area and instead benefit local people.

\section{Scale}

Three actor groups particularly appreciated the scale changes in tourism in their areas since 1992 - the tourists, businesses and institutions. The gatekeepers and resource controllers, less closely linked to front-line tourism, were less impressed by this dimension as a source of improvement. It was in the Irish, Spanish and Greek study areas (in which tourism is relatively new) where the actor groups were most impressed by the increasing scale of tourism. In the other countries scale was less of a major change.

Improving the scale of tourism came about by several different types of change. The simplest was more visitors attracted to an existing attraction which was being marketed better and benefiting from the general increase of tourism in the area Landštejn Castle in Česká Kanada is a good example of this. Scale could also be improved by attracting a new type of tourist to new facilities - the Vélo Route 
(cycling) in Basse Normandie (France) for example, and the Otter Reproduction and Recuperation Centre in North Cataluña. The development of a new style of tourism the soft tourism policy of the Parc Régional du Livradois-Forez, for example - not only increased tourist numbers, it also spread the tourists over a wider area of the Park which was recognised as a valuable scale change. The Casa Pilar in Valencia has increased its scale of visitation by a policy of successfully seeking quality designations and medals, while the Romanesque Interpretation Centre in North Cataluña has reduced the seasonality of tourism, another welcome scale change. Finally the Lake District Tourism and Conservation Partnership in Cumbria has reduced the environmental damage caused by tourism, which could have halted the sector's growth. Thus scale changes manifested themselves in several different ways.

\section{Sustainability}

In this project the term 'sustainability' refers to the physical effects of tourism development. Overall, actors saw clear gains from tourism in this respect. Businesses and institutions were particularly keen to acknowledge the gains in terms of sustainability whereas for the host communities, resource controllers, gatekeepers and tourists it was one of the below-average areas of improvement. That the resource controllers did not value the gains is significant, since many of them were controllers of land or other resources which would feature strongly in sustainable forms of tourism or would suffer if tourism were not sustainable. The tourists were not impressed by the opportunities to follow sustainable lifestyles in the countryside; some contrasted it with urban infrastructure where, for example, recycling and public transport are much better developed. Host communities were concerned about road 
traffic volumes, litter, footpath erosion and some new forms of tourism such as offroading in $4 \times 4$ vehicles. So there is some divergence between the more policy oriented players such as institutions and businesses, which can see the advances in sustainability in their spheres, and a more diluted message of progress from those nearer tourism on the ground.

In practice, the respondents were clear that sustainability could be achieved in several ways. So, the development of tourism in the World Heritage Site of Slavonice was seen as aiding the economic sustainability of the area. The restoration of the JHMD narrow-gauge railway in Česká Kanada sustained the industrial heritage of the area by providing a new tourist-oriented, year-round use for this redundant facility, and many of the other study areas had similar railway restoration projects. The Take Part event in the England / Wales Border sustained local arts and businesses and promoted an appreciation of the local landscape. The B4 Network of non-car transport in the English Lake District promoted sustainability in a more conventional sense by encouraging people to get out of their cars by integrating buses, boats, bikes and boots (the four Bs). The Lake District Tourism and Conservation Partnership aided sustainability by promoting small areas and attractions in less developed tourist areas which, by spreading the benefits of tourism away from the honeypots, meets the equity aspects of the sustainability paradigm. The Otter Reproduction and Recuperation Centre in North Cataluña was improving sustainability through its conservation work with otters and trout. In practice the respondents were taking a quite broad view of sustainability and finding evidence of it in different forms of tourism. 


\section{Endogeneity and embeddedness}

Although these two dimensions are distinct (see Table 1) they were linked in many of the respondents' minds. Embedding was assisted by endogeneity (the touristic use of local resources in the broadest sense). The gatekeepers and resource controllers were the keenest to stress how tourism in rural areas used local resources (including land, foods, employees, events, and cultural and natural sites). Indeed a stress on the 'local', and hence on distinctiveness, was a commonly used marketing tactic by the gatekeepers. The resource controllers were increasingly keen that their natural or cultural sites should be used for visitors' education and for additional income generation. The host communities linked embeddedness to empowerment, since the more control local people had over tourism, the more tourism's needs were rooted in local networks and priorities.

Endogeneity was achieved in several ways. It meant the promotion of the tourism potential of heritage sites (e.g. the Czech mediaeval town of Slavonice and the Romanesque churches of North Cataluña); of natural resources such as the winter snows for skiing in Kalavryta (Greece) and the marshland ecosystems of Les Ponts d'Ouve in Normandy; of local crafts and arts sold at the Michaelmas Fair in Bishop's Castle (England / Wales Border); and of adding value to the woodland assets of Grizedale Forest (Cumbria). This obvious use of local resources merged into the creation of networks to bring these resources, singly or collectively, to the notice of visitors. One example is the Lake District Peninsulas Tourism Partnership (Cumbria) which assists small local attractions to market themselves collectively. Another is the Cereza Montaña de Alicante Cooperative (Spain) which uses the local cherries as a 
brand image for all the producers of the area. A third example is the Women's Cooperative of Traditional Products in Evrytania (Greece) which promotes local foods, links them to tourism and supports local food producers to raise their competitiveness.

\section{Networking}

While networking is one of the major changes in the style of rural governance in recent years (promoted by the EU's LEADER projects for example) it was not seen as a major source of improvement in how tourism was being integrated into the study areas. It received the second lowest overall score for improvement. Only the gatekeepers recognised it as being one of the above-average areas for improvement while the tourists, resource controllers and host communities saw it as an area of below-average improvement. Interestingly the institutional respondents, the group one would expect to appreciate networking as a clear asset, did not rate it as a major source of increasing integration, though it is the institutions above all that have to achieve enhanced networking. The institutions were more appreciative of the improvements in networking than any other group, but they rated more highly the changes they had seen in the scale of tourism, its sustainability and empowering effects. The tourists were, perhaps unsurprisingly, the least aware of any changes in networking. The rhetoric of networking and partnerships as a device to improve management is pervasive, but not accepted as a major source of increased integration in tourism by the actors most concerned. The time demands of meetings and consultations were a burden for many, particularly for the smaller businesses which are so common in rural areas and find the staff time taken up by consultation quite 
onerous. The host communities too had noticed little improvement in networking so, whatever its benefits for policy, these are not evident or being communicated to those at the front line, the tourists and host communities. The most support for improvements from networking came from all the actor groups in Ireland and sporadically from other groups such as tourists and resource controllers in the Czech Republic, and gatekeepers in the UK.

Notwithstanding, there were some highly effective improvements in tourism networking which were credited with increasing the integration of tourism. One example was the National Park Administration of the Šumava Mountains in the Czech Republic which brought together the Regional Development Agency and many other groups; linked municipalities and businesses to organise social events; created integrated transport systems and ski trails systems; linked into the Czech Tourism Association to get national-level support for the area; and, through its Public Relations Centre, had good links with visitors and local communities. In Greece, the DEPAPOZ (the Kalavryta Municipal Organisation for Cultural Development and Quality of Life) is similar. It brought together for the first time the key local agencies. The B4 Network in Cumbria developed an integrated system of non-car based transport mainly for visitors, and this demanded extensive integration among many public agencies and private businesses, and liaison with the visitors.

\section{Complementarity}

On the face of it, complementarity was regarded as providing the least improvement. The total score for complementary was 23 per cent lower than that for empowerment 
and four of the actor groups placed it in their below-average category for improvement. However, the tourists and particularly the host communities placed complementarity at or near the top of their profile of the benefits from tourism. The division in perceptions was very marked between those more removed from tourism as an experience, who did not recognise fully how it had helped local people, and those 'on the ground' who did.

Examples of complementarity included the following very wide range of ways in which tourism was felt to enrich the local community. This list is in addition to the universally acknowledged benefits from job and income creation.

- Festivals attracted visitors and were also on themes popular with local people who appreciated they would not have had this cultural enrichment without the financial input from the visitors (e.g. festivals in Slavonice and Dobrá Voda in the Czech Republic, in Haut-Livradois (France) and in both UK study areas).

- A good local reputation based on one aspect of tourism spreads over to a good reputation for the area generally (e.g. from the Fourme d'Ambert cheese to the Livradois-Forez area generally).

- Services for the tourists can also be appreciated by local people who have been attracted to live in the area for the same qualities sought by the tourists (e.g. the ecological interpretation centre at the Les Ponts d'Ouve nature reserve in Normandy, and the maintenance of footpaths in the Lake District which benefits visitors and local walkers alike). 
- Tourism provides a source of income without which depopulation might occur (e.g. offshore island economies in the West Region (Ireland)).

- The preservation of an under-threat cultural feature for the use of visitors attracted by it and for local people who value it (e.g. the Irish language assisted by the GaelSaoire tourism promotional group in the West Region (Ireland)).

- Tourism helps services for local people operate all year, using peak-season profits to subsidise off-peak use, and this in turn encourages some off-season tourism.

- Providing local producers with another source of income as a visitor centre and shop (e.g. the olive oil and wine cooperatives in Sierra de Aitana (Spain), the Maříž pottery in Česká Kanada and in many other places.

- Tourism providing jobs (albeit usually low paid and seasonal and/or part time) for more vulnerable sections of society such as the less skilled, young people and women who might otherwise out-migrate (noted in the Alicante Mountains in Spain, and more generally).

- Tourism has funded the restoration of historic features such as the Abadia in Pont de Suert and the former postal walking routes in Spain, and narrow-gauge railways in several countries. 
- Tourism-inspired improvements to the appearance of a rather run-down area to increase its attractiveness to visitors, and which local people also appreciate (for example, Ulverston town centre in Cumbria, UK).

- The development a wider market for local products (e.g. the Take Part festival in Knighton in the England / Wales Border and the Made in Cumbria brand in the UK).

In all these many ways tourism had helped the quality of local life in ways which those 'on the ground' (the tourists and local people) will see daily whereas they are less recognised by those less closely involved or further away. The potential benefits from tourism are many, widespread, complex and subtle, straddling the artificial division of tourism impacts into 'economic', 'social', 'cultural' and 'environmental'.

\section{An example of well integrated tourism}

The structure of this paper has been based on the seven dimensions of integration which were used by SPRITE project. Examining each dimension separately shows how the concept can be developed in different places and forms. However, by separating out the individual benefits from a range of projects one loses the sense of how a single development can achieve improvements in all or most of the seven dimensions. One gets a sense of these multiple benefits when, in the paragraphs above, one development is mentioned more than once as improving the integration of rural tourism on more than one dimension. The same development can affect life in several ways, as is implied by the concept of integration. Below we give one 
particularly striking example of such a multi-dimensional, multi-actor assemblage of gains.

Lake District Tourism and Conservation Partnership in Cumbria (UK) is a visitor pay-back scheme and is a good example of well integrated rural tourism which benefits many actors and improves on several of the seven dimensions of tourism value.

1. It links conservation groups and conservation aims with profit-seeking businesses in the tourism sector - the latter act as collectors of visitor donations and are themselves match-funding corporate donors (this improves networking beyond the usual community leaders and ex officio consultees, and embeddedness).

2. It links individual tourists with the repair of the environmental damage done by tourists collectively in a much-used tourist area (sustainability, embeddedness and local empowerment).

3. The Partnership provides local benefits from tourism in small and less iconic tourist areas which might otherwise experience predominantly the negative side of tourism (sustainability).

4. Local effort is linked to the national scene through support from national figures (e.g. H.R.H. The Prince of Wales) and national awards (e.g. Sieff Award, Business in the Community Awards for Excellence) (networking beyond the region).

5. The Partnership is well thought of by all the other actors in the Lake District tourist community which improves its effectiveness and gets it invited onto committees and partnerships (sustainability and networking). 
6. It brings key tourism people together on its Board of Directors (networking and embeddedness).

7. Individuals can make a difference on a small scale by protecting the landscape that is a key element in the local tourism product (endogeneity and empowerment).

8. It prevents environmental damage halting the growth of the sector (scale).

9. Its work protects the environment for local residents who value it as do the visitors (complementarity).

10. The Partnership is a means of gathering match funding for larger environmental bids (e.g. from the UK National Lottery Fund).

This example shows that it is possible for one well-designed activity to benefit simultaneously different actor groups and localities and improve the area on several dimensions. The enhanced integration of rural tourism can therefore be achieved on two scales - at the macro scale of people's overall view of tourism in all its forms, and at the micro scale of individual projects. If all individual tourism projects integrated as well as this Cumbrian example, then at a macro-scale rural tourism in general would be better integrated. Where individual projects achieve only limited integration separately, then the directors of tourism policy need to ensure that collectively the diversity of tourism projects achieves that integration.

\section{Conclusion}

This paper has focused on a practical means by which one might measure the integratedness of rural tourism in its locale. It is based on a multi-dimensional and multi-actor approach which is consistent with the definition of 'integrated rural 
tourism' that is proposed in the first paper in this volume (Saxena, et al., 2007). The degree of spatial resolution built into the methodology allows one to test the hypothesis that tourism may become integrated to different extents and in distinctive ways across Europe, responding to local resources, opportunities and political and social cultures. It allows one to use the concept of 'integrated rural tourism' as an operational monitoring tool because one can now measure 'integratedness'.

The key element of the methodology is to measure the degree of integration by using a single metric across all seven dimensions, namely the actors' perceptions of the relative changes in the seven dimensions of integration over a ten-year period. This social-constructivist index allows one to calculate an overall or composite profile of integration and to identify its components, that is, where, why and for whom integration has been faster or slower than normal. In short, this paper describes a perception- and evidence-based measure of integration. More statistically based measures have a role to play, but they suffer technical weaknesses discussed in this paper which limit their usefulness in practice. A perception-based approach complements the statistical ones.

The perceived increase in the integration of tourism in these study areas has been considerable since 1992; and the potential for further improvement is at least as great again. The paper has shown that the seven dimensions of tourism have improved at different rates and that the various actor groups have identified distinctive aspects of tourism as the ones where they have seen improvements. The examples of highvalue, well integrated tourism described in this paper show in a practical way the range of means by which the broad concept of integrated rural tourism can be 
improved. Some types of rural tourism have been shown to be capable of achieving multi-dimensional, multi-actor benefits for a community; others were of more limited value or even divisive. The use of a range of case studies to illustrate the changes has shown the variety of ways in which tourism can have effects and hence its sensitivity to the local context in which it occurs. The method has also highlighted the different perceptions among the actor groups as to the effects of, and improvements in tourism. The groups nearest 'tourism as experienced' (the visitors and local communities) did not have the same set of views of tourism's evolution as those more institutionally located.

The methodology developed here is novel and has operationalised a means of allowing stakeholders and practitioners to assess the changes in tourism value, broadly defined. This gives tourism and resource managers a means of tracking changes in integration, perhaps as a result of tourism management or policies. The methodology is clear enough to be operated at various scales and intensities and can be repeated periodically to gauge trends in policy effectiveness.

The main purpose of tourism is arguably to benefit all aspects of an area and all its stakeholders, economically, socially and culturally while protecting the physical environment. This methodology measures in a consistent way how close each area is to that ideal form of tourism and, by its focus on exemplars of well integrated tourism, has supplied benchmarks and ideas for future policy. The dynamic aspect of the model - change in tourism value - focuses attention on sustained tourism value creation (Ryan 2002) (non-damaging and balanced growth) which is the requirement 
for any area which wishes to retain its competitiveness in an era when the crossfertilisation of individual ideas and practices can be rapid.

\section{Acknowledgment}

This paper is based on a collaborative programme of research funded under the EU's Quality of Life and Management of Living Resources programme (QLK5-CT-200001211 - SPRITE) and undertaken by the Universities of Wales (Aberystwyth) (coordinator), Caen, Patras, Ireland (Galway), Valencia, Lancaster and Coventry, together with the Institute of Landscape Ecology (České Budějovice), CEMAGREF (Clermont Ferrand) and Teagasc (Dublin).

\section{References}

Aronsson, L. (2000) The development of sustainable tourism. London: Continuum.

Butler, R. (1999) Problems and issues of integrating tourism development, In D.G.

Pearce \& R. Butler (eds) Contemporary issues in tourism. London: Routledge.

Cater, E. (1994) Environmental contradictions in sustainable tourism. Geographical Journal 161, 21-28

Commission of the European Communities (2003) Basic Orientations for the Sustainability of European Tourism COM(2003) 716 final (Brussels: Commission of the European Communities). 
European Environment Agency (2005) Agriculture and environment in EU-15: the IRENA indicator report No 6 Copenhagen: European Environment Agency.

Hemphill, L., Berry, J. \& McGreal, S. (2004) An indicator-based approach to measuring sustainable urban regeneration performance: Part I, conceptual foundations and methodological framework, Urban Studies, 41, pp. 725-755.

Jenkins, T. \& Oliver, T. (2001) Integrated tourism: a conceptual framework. SPRITE Working Paper 1. Aberystwyth: University of Wales.

McCool, S. F. \& Moisey, R. N. (eds) (2001) Tourism, recreation and sustainability. (Wallingford: CABI Publishing).

Miller, G. \& Twining-Ward, L. (2005) Monitoring for a sustainable tourism transition: the challenge of developing and using indicators. (Wallingford: $\mathrm{CABI}$ Publishing).

Ryan, C. (2002) Equity, management, power sharing and sustainability - issues of the 'new tourism', Tourism Management, 23, pp. 17-26.

Saxena, G., Clark, G., Oliver, T. and Ilbery, B. (2007) Conceptualising integrated rural tourism, Tourism Geographies, vol. (part), pp. ???-???. 
Stabell, C.B. \& Fjeldstad, O.D. (1998) Configuring value for competitive advantage: on chains, shops and networks, Strategic Management Journal, 19, pp. 413-437.

Stabler, M. (1997) Tourism and sustainability: principles to practice. Wallingford: CABI Publishing.

Stamboulis, Y. \& Skayannis, P. (2003) Innovation strategies and technology for experience-based tourism, Tourism Management, 24, pp. 35-43.

Swarbrooke, J. (1999) Sustainability and tourism management. Wallingford: CABI Publishing.

Talluri, S., Baker, R.C. \& Sarkis, J. (1999) A framework for designing efficient value chain networks, International Journal of Production Economics, 62, pp. 133-144.

World Tourism Organization (2001) Global Code of Ethics for Tourism (Madrid: World Tourism Organization). 